\title{
Fiscal decentralization and its impact on industrial development in Jambi Province
}

\author{
M. Syurya Hidayat ${ }^{1 *}$; Faradila Herlin ${ }^{2}$ \\ ${ }^{1)}$ Development Economics Department, Faculty of Economics and Business, \\ Universitas Jambi, Indonesia \\ 2) Development Economics Department, Faculty of Economics and Business, \\ Universitas Muhammadyah Jambi, Indonesia
}

*To whom correspondence should be addressed. E-mail: syuryahidayat@gmail.com

\begin{abstract}
This study aims to analyze: 1) factors influencing the degree of fiscal decentralization in Jambi Province; 2) the influence of the degree of fiscal decentralization on the industrial sector in Jambi Province. The analysis model is the panel data regression. The results showed that, first, the economic level, the amount of regional spending, and the investment level significantly influence the degree of fiscal decentralization in Jambi Province. Second, there is a significant impact of the degree of fiscal decentralization on the development of the industrial sector in Jambi Province. This study recommends increasing local own-source revenue in order to improve the degree of fiscal decentralization. Furthermore, the allocation of regional expenditure must be directed towards direct expenditure, especially capital expenditure, which is related to industrial development in Jambi Province.
\end{abstract}

Keywords: Fiscal decentralization, GRDP, Investment, Regional expenditure

JEL Classsification: G38, L52, O23

\section{INTRODUCTION}

Regional autonomy and fiscal decentralization policy in Indonesia is a manifestation of the central government authority by giving rights to regional governments to carry out regional economic activities, based on the aspirations and needs of the community. It is expected that there will be an even distribution of development outcomes between regions with this policy (Shankar \& Shah, 2003; Canaleta, Arzoz \& Garate, 2004).). Fiscal decentralization will deliver optimal benefits if it is followed by adequate financial capacity by the autonomous region (Liu \& Zhang, 2018).

According to the Law No. 33 of 2004, local revenue sources in the context of implementing fiscal decentralization consist of Local Own-Source Revenues, Balance Funds, and Other Legitimate Revenues. The enactment of Law No. 32 of 2004 and Law No. 33 of 2004 provides opportunities for regions to improve its financial performance, in order to realize regional independence and reduce fiscal dependence on the central government. Increased on the regional independence level is closely related to the capacity of the region to manage its Local Own-Source Revenue (Putra \& Hidayat, 2016). 
Jambi Province is one of the provinces in Indonesia. Many efforts had been done in increasing independency and in reducing fiscal dependence of regencies/cities in the province. However, out of 11 regencies/cities, there is a gap concerning the degree of fiscal decentralization between regencies/cities.

Fiscal decentralization as measured by the degree of fiscal decentralization is expected to have impact on the regional economic development (Devarajan, Swaroop, \& Zou, 1996; Soejoto, Subroto \& Suyanto, 2015). The greater the degree of fiscal decentralization means the greater the budget for regional expenditure. If the expenditure is allocated to sectors related to industrial development, it will have an impact on industrial development (Gbettor, Adjimah \& Tibu, 2014). If this multiplier effect continues in the development of existing industries, the welfare of community will be achieved through increase revenues. Therefore, inequality of the degree of fiscal decentralization between regencies/cities in Jambi Province will also have an impact on the imbalance of community welfare between them.

Several research findings found that efforts to increase the degree of fiscal decentralization in regencies/cities in Jambi Province are influenced by several internal and external factors. Some of them are the economic level (GRDP), the amount of regional spending/expenditure, and the investment level (Paniza, 1999; Globerman \& Shapiro, 2002; Bacarreza, Varquez,Yedgenov, 2016; Sari, Thjahjono \& Turino, 2018; Armaja, Ridwan \& Aliamin, 2015).

Based on the explanation, this study aims to analyze: 1) factors influencing the degree of fiscal decentralization in Jambi Province; 2) the influence of the degree of fiscal decentralization on the industrial sector in Jambi Province.

\section{METHODS}

This research used a quantitative descriptive method that is based on the secondary data analysis. Secondary data in the study include data on Local Own-Source Revenue, total regional revenue, Gross Regional Domestic Product, regional expenditures, Investment level, and number of industries.

Data observed were limited from 2011 to 2017 data. The data analyzed were obtained from the Regional Development Planning Agency (BAPPEDA), the Statistics Indonesia (BPS), and Finance Department of Regencies/Cities in Jambi Province. Descriptive quantitative research is conducted to identify the factors influencing the degree of fiscal decentralization of regencies/cities in Jambi Province, and to analyze the impact of the degree of fiscal decentralization on the industrial sector development in Jambi Province. Based on these considerations, the Panel Data Regression Analysis Model is used as shown in equation (1) and equation (2):

$\mathrm{DDF}_{\mathrm{it}}=\beta_{0}+\beta_{1} \mathrm{LnPDRB}_{\mathrm{it}}+\beta_{2} \mathrm{LnBD}_{\mathrm{it}}+\beta_{3} \mathrm{LnINV}_{\mathrm{it}}+\mu_{\mathrm{it}}$

$\mathrm{IND}_{\mathrm{it}}=\beta_{0}+\beta_{1} \mathrm{DDF}_{\mathrm{it}}+\mu_{\mathrm{it}} \ldots$

In which:

DDF $\quad=$ Degree of fiscal decentralization

IND = Industrial development

$\beta_{0} \quad=$ Constant

$\beta_{1} \beta_{2} \beta_{3} \quad=$ Regression coefficient

PDRB = Gross Regional Domestic Product

$\mathrm{BD} \quad=$ Regional expenditure

INV $\quad=$ Investment 


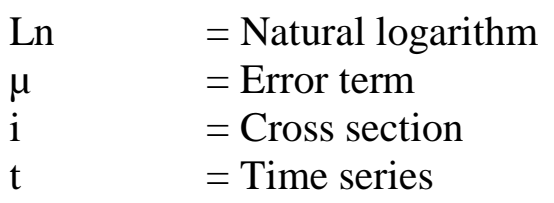

To determine the estimation model of panel data regression, three models are used namely the common effect model, the fixed effect model, and the random effect model. From these models, it will be determined one best estimation model by conducting several tests. First, the Chow Test or Likelihood Test Ratio is carried out to find out whether the Fixed Effect Model is better than the Common Effect Model by doing Fstatistical test. Second, the Hausman Test is used to determine whether the Fixed Effect Model is better than the Random Effect Model. Hausman's statistical testing follows the Chi-square distribution based on Wald's criteria. Third, the Lagrange Multiplier Test is used to determine whether the Random Effect Model is better than the Common Effect Model. It can be done by comparing the chi-square probability value to a certain significant level $(\alpha)$. After getting the best estimation model, $\mathrm{R}^{2}, \mathrm{~F}_{\text {count }}$ and $\mathrm{t}_{\text {count }}$ will be analyzed.

The Degree of fiscal decentralization is a comparison the realization of local ownsource revenue (Pendapatan Asli Daerah/PAD) with total regency/city regional revenue in Jambi Province in 2011-2017 in per cent (\%). GRDP is GRDP value in each regency/city in Jambi Province in 2011-2017 based on the constant (2010) prices in units of millions of rupiah per year.

Other independent variables are regional expenditure and investment level. Regional expenditure is the amount of budget available for the regional expenditure in Regional Government Budget (Anggaran Pendapatan dan Belanja Daerah/APBD) of each regency/city in Jambi Province, stated in units of millions of rupiah per year. As for investment, it means the amount of domestic investment (Penanaman Modal Dalam Negeri/PMDN) and foreign investment (Penanaman Modal Asing/PMA) in the regencies/cities of Jambi Province, stated in units of millions of rupiah per year. The dependent variable in equation (2) is industry, which has an operational definition as the development of the number of industry in each regency/city in Jambi Province, stated in units of per cent per year.

\section{RESULTS AND DISCUSSION}

Based on the analysis of GRDP of regency/city in Jambi Province, two regencies had the largest number of GRDP in 2017. They were Tanjung Jabung Barat of Rp. 27.361 billion and Jambi City of Rp. 12.728 billion and each region provided contribution to GRDP of Province Jambi as much as 20.04 percent and 12.98 percent respectively.

Regencies/Cities that have the smallest number of GRDP in Jambi Province were Sungai Penuh City of Rp. 4.192 billion and Kerinci Regency of Rp. 5.792 billion, with the contributions of 3.07 percent and 4.24 percent of Jambi Province's GRDP. If it was compared to the number in 2011, Tanjung Jabung Barat Regency increased its GRDP by 5.26 percent per year while Jambi City increased its GRDP by 6.09 percent per year.

For the regional expenditure, the capacity of each regency/city is very varied. In 2011, regional expenditure of Jambi City was Rp. 797.797 billion and was the highest among other regencies/cities. The lowest regional expenditure was from Tanjung Jabung Timur Regency of Rp. 314.212 billion. Whereas in 2017, the highest regional expenditure was still from Jambi City and the lowest was Sungai Penuh City of Rp. 
714.887 billion. This shows that Jambi City has better ability to manage its regional finance.

Investment level of regency/city reflects the characteristics of the regional economic potential. Tanjung Jabung Barat Regency always has the highest investment level compared to other regencies/cities. It reached Rp. 25.966 trillion or 72.37 percent of the total investment in Jambi Province. This number can be justified as there are several large-scale mining and plantation companies in Tanjung Jabung Barat Regency. Likewise, Bungo Regency (of Rp. 2.444 trillion or 6.81 percent), Muaro Jambi Regency (of Rp. 2.369 trillion or 6.60 percent) and Batang Hari Regency (of Rp. 1.437 trillion or 4.01 percent) are the regions based on the plantation and mining sector. The exception is for Jambi City that has a quite stable investment value of Rp. 1.525 trillion (4.25 percent) based on the industry, trade, and services sectors. Based on its development, investment level of each region/city shows a proportional development since 2011.

The explanation of variables above conceptually affects the degree of fiscal decentralization of each regency/city in Jambi Province. Based on the factual data in 2017 , there is only one region that has a degree of fiscal decentralization above ten per cent, namely Jambi City (18.30 percent), while others have it below ten percent. Sungai Penuh City has the lowest degree of fiscal decentralization at 5.18 percent. If it was compared to the number in 2011, Jambi City showed a great development of fiscal decentralization degree, from 11.30 percent to 18.30 percent (an increase of 7 percent). This indicated that the capacity of Jambi City to increase its Local Own-Source Revenue is quite good, so it can increase its degree of fiscal decentralization.

Further analysis was carried out by testing the panel data regression model, through the Chow test and the Hausman test. Then, the best estimation model was obtained, which is the Fixed Effect Model. This model will analyze the influence of economic level, amount of direct expenditure, and investment level on the degree of fiscal decentralization in Jambi Province. The Fixed Effect Model regression equation is shown in the Table 1.

Table 1. Fixed effect model regression test results

\begin{tabular}{lrrrc}
\hline Variable & Coefficient & Std. Error & t-Statistic & Prob. \\
\hline C & 198.5018 & 79.94128 & 2.483095 & 0.0224 \\
LN(PDRB) & 14.71529 & 7.168716 & 2.052709 & 0.0351 \\
LN(BL) & 11.27111 & 5.206769 & 2.164703 & 0.0200 \\
LN(INV) & 0.199716 & 0.097082 & 2.057189 & 0.0362 \\
\hline Fixed Effects (Cross) & & & & \\
\hline Batang Hari & 0.059702 & & & \\
Bungo & 1.352162 & & & \\
Kerinci & 3.396048 & & & \\
Merangin & -2.593642 & & & \\
Muaro Jambi & -4.285943 & & & \\
Sarolangun & 0.190411 & & & \\
Tanjung Jabung Barat & -4.505039 & & & \\
Tanjung Jabung Timur & -5.360362 & & & \\
Tebo & -1.842154 & & & \\
Jambi City & 4.591198 & & & \\
Sungai Penuh City & -3.874712 & & & \\
\hline R-squared & 0.752034 & & & \\
\hline F-statistic & 22.78224 & & & \\
\hline
\end{tabular}

Source: Data processed 
The Table 1 show that GRDP, the amount of regional expenditure and the investment level influence the degree of fiscal decentralization of regencies/cities in Jambi Province. This is shown by the F-statistic value of 22.78224 with a prob value of 0.0230 . It means that the error rate of the estimation model is only 2.3 percent. The influence of GRDP, regional expenditure, and investment level of regencies/cities in Jambi Province is shown by the $\mathrm{R}^{2}$ coefficient of 0.752034 . This means that 75.20 percent of independent variables in the estimated model are able to explain the dependent variables.

In partial test, there is a significant effect of each independent variable on the dependent variable. GRDP and regional expenditure variable significantly influence with a prob value of 0.0351 and 0.0200 respectively. Likewise, investment level variable influence significantly with a prob value of 0.0362 . Estimation results are in line with the finding of Panizza (1999) which concluded that economic level of a country which is reflected in GDP will has a correlation with the degree of fiscal decentralization, in addition to other factors. Whereas Frank \& Martinez-Vazquez (2014) stated that infrastructure has a correlation with fiscal decentralization. In the case of Indonesia, the availability of infrastructure is very dominantly provided by the state through government spending. The same opinion was also expressed by Bacarreza, Varquez \& Yedgenov (2016).

The results as shown in the Table 1 emphasize a need for serious attention from regency/city government in Jambi Province to always make efforts to improve the local economy (Cull, Demirgüç-Kunt, \& Lin, 2013), to increase the amount of direct spending, especially capital expenditure and to increase regional investment opportunities in order to increase the degree of fiscal decentralization (Sari, Thjahjono $\&$ Turino, 2018). Serious regards to this matter will make the regency/city government in Jambi City have more opportunities in designing and planning their programs in regional development, because the local governments have independence in their expenditure budget.

Further analysis showed that constants from the estimation result have very varied values. The values of constants from each regency/city can be categorized into three groups. The categorization was carried out because geographical characteristics can also influence the fiscal decentralization (Alexeev \& Mamedov, 2017). First, there are regencies/cities that have positive constants above one, namely Bungo Regency, Kerinci Regency, and Jambi City. This means that if all independent variables in the model are zero then the degree of fiscal decentralization for each regency/city will have a positive value above one. This condition reflects the regency/city has quite large local ownsource revenue, so it has a level of independence in its budget (Ibrahima \& Alagidede, 2018). Second, the regencies/cities that have zero constant values are Batang Hari Regency and Sarolangun Regency. This means that if all the independent variables in the model are zero then the fiscal decentralization degree of each regency will be around zero. Regencies in this group show relatively a financial dependence on the central government. Third, there are regencies that have negative constant values. Regencies/Cities in this group are those with a very low degree of fiscal decentralization or with a very high financial dependency on the central government.

Next, there is the estimation result of the impact of fiscal decentralization degree on the industry development in regencies/cities in Jambi Province. The estimation results show that there is a positive and significant effect of fiscal decentralization 
degree on the industry development in regencies/cities in Jambi Province. This is shown by the t-value of 2.1525 or with a prob value of 0.0360 . The impact of fiscal decentralization degree on the industry development in regencies/cities in Jambi Province is shown by the $\mathrm{R}^{2}$ value of 81.19 percent. Details are shown in the Table 2.

Table 2. Simple regression model estimation results

\begin{tabular}{crrrc}
\hline Variable & Coefficient & Std. Error & t-Statistic & Prob. \\
\hline C & 202.7014 & 85.34125 & 2.375186 & 0.0213 \\
LN(PDRB) & 15.21537 & 7.068414 & 2.152586 & 0.0360 \\
\hline \multicolumn{5}{c}{} \\
\hline
\end{tabular}

Source: Data processed

These results are in line with the results of Vazquez, Penas \& Sacchi (2016) who conducted a survey of the impact of fiscal decentralization on the economy, society, and politics. His research indicated that there is an impact of fiscal decentralization on the economy, including the industry development. On the other hand, Gbettor, Adjimah \& Tibu (2014) stated that through fiscal decentralization, there would be poverty reduction thanks to the economic growth, including activities in industry sector.

\section{CONCLUSIONS AND RECOMMENDATIONS}

\section{Conclusions}

Based on the results, several things can be concluded. First, economic developments, regional expenditure by the government and investment level have a significant effect on the fiscal decentralization degree in Jambi Province. Second, there is a significant influence of fiscal decentralization degree on the development of industry in Jambi Province.

This conclusion offers an understanding that the degree of fiscal decentralization of a region is closely related to the role of government through regional expenditure and the role of the private sector through the investment level. If there is a positive synergy, it will have a positive impact on the fiscal decentralization degree of the region. All of them will be reflected in the industry development in the region concerned.

\section{Recommendations}

Commitment of government in industrial development in Jambi Province must be the main concern. One that can influence it is related to the degree of fiscal decentralization. Therefore, government of Jambi Province has to make an effort to do a number of things. First thing is to maintain the economic growth to be more progressive. Second effort is to increase local own-source revenue in order to increase its regional expenditure sources. Thus, it is easier to increase direct expenditure. Third effort is to create conducive investment climate, both in the form of infrastructure and in the form of regulations. If those three things are realized, it will have an impact on improving the degree of fiscal decentralization. So it will also have an impact on the development of industry in Jambi Province.

\section{REFERENCES}

Alexeev, M. \& Mamedov, A. (2017). Factors Determining Intra Regional Fiscal Decentralization in Russia and the US. Russian Journal Of Economics, 3(4), 425444. http://dx.doi.org/10.1016/j.ruje.2017.12.2007 
Armaja, Ridwan, I. \& Aliamin. (2015). Pengaruh Kekayaan Daerah, Dana Perimbangan, dan Belanja Daerah terhadap Kinerja Keuangan (Studi Pada Kabupaten/Kota Di Aceh). Jurnal Perspektif Ekonomi Darussalam, 3(2), 168-181. https://doi.org/10.24815/jped.v3i2.8229

Bacarreza, G.C., Varquez, J.M. \& Yedgenov, B. (2016). Reexamining the determinants of fiscal decentralization: what is the role of geography?. Journal of Economic Geography, 17(6), 1209-1249. https://doi.org/10.1093/jeg/lbw032

Cull, R., Demirgüç-Kunt, A., \& Lin, J. Y. (2013). Financial structure and economic development: A reassessment. World Bank Economic Review, 27(3), 470-475. Available at: https://elibrary.worldbank.org/doi/abs/10.1093/wber/lht006

Devarajan, S., Swaroop, V., \& Zou, H. (1996). The composition of public expenditure and economic growth. Journal of monetary economics, 37(2), 313-344. https://doi.org/10.1016/S0304-3932(96)90039-2

Frank, J. \& Martinez-Vazquez, J. (2014). Decentralization and Infrastructure: From Gaps to Solutions. International Center for Public Policy Working Paper Series, at AYSPS, GSU paper1405, International Center for Public Policy, Andrew Young School of Policy Studies, Georgia State University. Available at: https://icepp.gsu.edu/files/2015/03/ispwp1405.pdf

Gbettor, E.M.A., Adjimah, H.P. \& Tibu, S.K. (2014). Fiscal Decentralization And Poverty Reduction: Citizens View. Jurnal of Social Economics Research, 1(6), 118-128. http://www.pakinsight.com/?ic=journal\&journal=35.

Canaleta, C.G., Arzoz, P.P \& Garate, M.R. (2004). Regional Economic Disparities and Decentralisations. Urban Studies, 41(1), 71-94. https://doi.org/10.1080\%2F0042098032000155696

Globerman, S., \& Shapiro, D. (2002). Governance infrastructure and US foreign direct investment. Journal of International Business Studies, 34(1), 19-39. Available at: https://link.springer.com/article/10.1057\%2Fpalgrave.jibs.8400001

Ibrahim, M. \& Alagidede, P. (2018). Effect of financial development on economic growth insub-Saharan Africa. Journal of Policy Modeling, 40(6), 1104-1125. https://doi.org/10.1016/j.jpolmod.2018.08.001

Liu, G. \& Zhang, C. (2018). Does financial structure matter for economic growth in China, China Economic Review. https://doi.org/10.1016/j.chieco.2018.06.006

Panizza, U. (1999) On the determinants of fiscal centralization: theory and evidence. Journal of Public Economics, 74(1), 97-139. https://doi.org/10.1016/S00472727(99)00020-1

Putra, R. \& Hidayat, S. (2016). Tingkat Kemandirian Keuangan Daerah dan Hubungannya Dengan Pertumbuhan Ekonomi Provinsi Jambi. Jurnal Perspektif Pembiayaan dan Pembangunan Daerah, 3(4), 243 - 256. Available at: https://online-journal.unja.ac.id/index.php/JES/article/view/3526

Sari, R.P., Thjahjono, H. \& Turino. (2018). Analysis Of Financial Performance In Public Sector (A Case Study in Lamongan, East Java - Indonesia). Journal of Accounting and Strategic Finance, 1(1), 82-90. Available at: http://jasf.upnjatim.ac.id/index.php/jasf/article/view/35

Shankar, R., \& Shah, A. (2003). Bridging the economic divide within countries: A scorecard on the performance of regional policies in reducing regional income disparities. World Development, 31(8), 1421-1441. doi:10.1016/S0305750X(03)00098-6 
Soejoto, A., Subroto, W.T. \& Suyanto, Y. (2015). Fiscal Decentralization Policy In Promoting Indonesia Human Development. International Journal of Economics and Financial Issues, 5(3), 763-771. Available at: https://www.econjournals.com/index.php/ijefi/article/view/1314

Vazquez, J.M, Penas, S.L. \& Sacchi. A. (2016). The Impact Of Fiscal Decentralization: A Survey. Journal of Economic Surveys, 31 (4), 1095 - 1129. https://doi.org/10.1111/joes.12182 